\title{
Solar Energy System Based Impedance-source Inverter for Grid Connected System
}

\author{
S. Kamalakkannan ${ }^{1}$, D. Kirubakaran ${ }^{2}$ \\ ${ }^{1}$ Sathyabama University, Chennai-119, India \\ ${ }^{2}$ St. Joseph's Institute of Technology, Chennai-119, India
}

\begin{tabular}{l} 
Article Info \\
\hline Article history: \\
Received Mar 15, 2018 \\
Revised May 2, 2018 \\
Accepted May 22, 2018 \\
\hline Keyword: \\
Impedance-source inverter \\
Maximum Power Point \\
Tracking (MPPT) \\
Solar energy system
\end{tabular}

Article Info

Article history:

Received Mar 15, 2018

Revised May 2, 2018

Accepted May 22, 2018

\begin{abstract}
In this work, the fickleness of solar energy can be overcome by using Maximum Power Point Tracking Algorithm (MPPT). Perturb and Observation ( $\mathrm{P} \& \mathrm{O})$ MPPT algorithm accomplish fast the maximum power point for rapid change of environmental conditions such as irradiance intensity and temperature. The MPPT algorithm applied to solar system keep the boost converter output constant. Output from boost converter is taken to three phase impedance-source inverter with RL load and grid system. Impedance-source inverter performs the transformation of variable DC output of the solar system in to near sinusoidal AC output. This near sinusoidal AC output consecutively is served to the RL load first and then to grid system. The simulation is carried out in matlab/simulink platform both for RL load and grid system and the simulation results are experimentally validated for RL load arrangement only.
\end{abstract}

Copyright ()$^{2} 2018$ Institute of Advanced Engineering and Science. All rights reserved.

\section{Corresponding Author:}

S. Kamalakkannan,

Sathyabama University,

Chennai-119, India.

Email: mypkg194@gmail.com

\section{INTRODUCTION}

Amongst biomass, geothermal, hydro and solar energy, solar energy is considered as the most hopeful energy substitute and are potential sources for bulk power generation. Unfortunately, solar characteristics rely on ecological conditions like irradiance intensity and temperature [1]. The fickleness of solar energy transpires us to find an active method to leverage it when they are accessible. The fickleness of solar energy can be overcome using MPPT. Perturb and observation (P\&O) MPPT algorithm can execute maximum power point for rapid change in environmental conditions such as irradiance, intensity and temperature. Therefore maximum power point tracking based inverter [2] is requisite in between the solar energy system source and the load arrangement. Many methods and algorithms for tracking the maximum power from the solar energy system are available. $\mathrm{P} \& \mathrm{O}$ [3] and incremental conductance algorithms are commonly used for the reasons of their appropriateness and ease to realize for solar photovoltaic panel. To resolve the problem of undulations nearby the maximum power point under steady state conditions and poor tracking competency during changeable irradiance traditional $\mathrm{P} \& \mathrm{O}$ algorithms, the variable step size $\mathrm{P} \& \mathrm{O}$ has been brought in [4-5]. The various families of power converters have been intended to interface the renewable solar resource for different applications [6]. Owing to development of power electronics and embedded system techniques, control and implementation of renewable energy systems are made promising.

The output from solar system is fed as input to boost converter. The MPPT algorithm is applied to solar system in order to keep the boost converter output constant [7]. The output from boost converter is taken to three phase impedance-source inverter with load arrangement first and then to grid system. The three phase impedance -source inverter is operated in closed loop control for voltage and frequency 
synchronization. Eventually three phase impedance-source inverter output with LC filters will produce sinusoidal output which is fed to the load first and then to grid system. Thus, a control algorithm with boost converter [8] and three phase impedance-source inverter is proposed to utilize the renewable energy resource to their maximum level. The proposed three phase impedance-source inverter can either buck or boost AC output, a scenario that could not be achieved in conventional Current Source and Voltage Source Inverters (CSI and VSI) [9]. Moreover, the impedance-network of three phase impedance-source inverter comprising a pair of capacitors and inductors forms the second order filter that filters unwanted voltage sags thereby reducing the current total harmonic distortion and improving the quality of power. Consequently enhanced power quality without sag and lesser total harmonic distortion is given to load [10-15].

Amongst the different controllers, PID controller is proposed for grid connected solar based impedance-source inverter system [11-15]. PD and PI controller improves transient and state responses respectively. Henceforth, combination of both PD and PI controllers improves overall time response of the system. However it affects both transient as well as steady state performance of the system. For effective result it must be tuned properly. There is no offset error in this controller. It makes the system response fast and reduces the settling time.

\section{IMPEDANCE-SOURCE INVERTER}

Impedance-source inverter shown in Figure 1 has impedance-network on its DC side. The exclusive impedance network consists of passive components (Inductors and Capacitors) that give single-stage conversion.

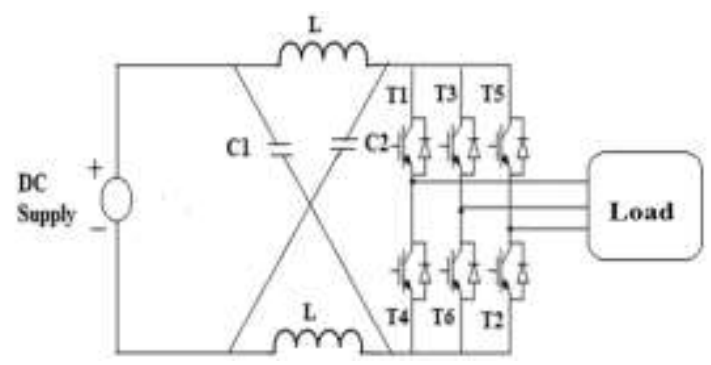

Figure 1. Schematic of impedance-source inverter

A second-order filter which handles the unwanted voltage sags in a DC voltage source is formed by the impedance network. It reduces the harmonics in the current due to dual inductors in impedance-source network as well as in rush current [13-14]. Existence of two inductors and capacitors in impedance-source network permits both the switches in the same leg in ON state, concurrently named as "shoot through state". This state provides boosting ability to the inverter without destructing the switching devices. In this state, energy is transmitted from capacitor to inductor and hence impedance-source network gains the voltage boosting ability. A diode is mandatory to avoid the discharge of charged capacitor through the source. The major advantages of impedance-source inverter are:

1. Can step down (buck) or step up (boost) voltage outputs which are not possible with voltage source and current source inverters.

2. Produce any anticipated voltage outputs, more than the line voltage, irrespective of the voltage input, thus lessen the ratings of motor.

3. It provides ride-through at the instance of voltage sags minus any additional circuits

4. Less affected by electro magnetic inference (EMI) noise and

5. Improve power factor and reduces harmonic current.

\subsection{Analysis of impedance network}

The three states in which the impedance-source inverter functions are shoot-through state, active state and zero state. One among the two switches of each limb will conduct in active state producing fixed output across the load; on the other hand, either switches in upper arm or switches in lower arm will conduct in zero state producing no output across the load. But the load terminals get short-circuited by upper as well 
as lower switches of either one or both limbs at the shoot-through state thus not producing any output across the load [16].

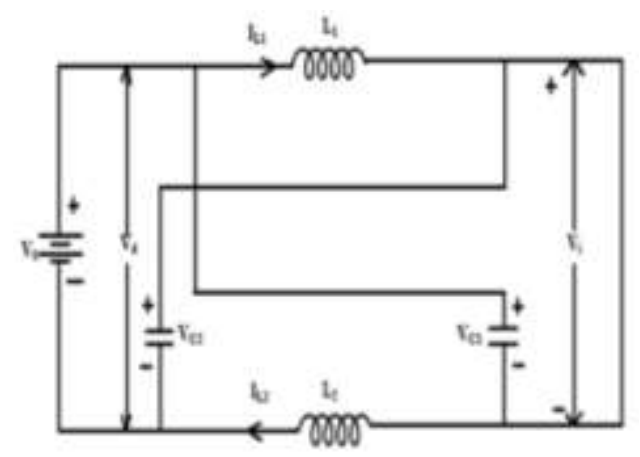

Figure 2. Impedance network

As the impedance network shown in Figure 2 is assumed symmetric, capacitors $\left(\mathrm{C}_{1}\right.$ and $\left.\mathrm{C}_{2}\right)$ and inductors $\left(L_{1}\right.$ and $\left.L_{2}\right)$ have the same values of capacitance and inductance respectively [17-19]. Hence, capacitor and inductor voltages are

$$
\mathrm{V}_{\mathrm{C} 1}=\mathrm{V}_{\mathrm{C} 2}=\mathrm{V}_{\mathrm{C}}, \mathrm{V}_{\mathrm{L} 1}=\mathrm{V}_{\mathrm{L} 2}=\mathrm{V}_{\mathrm{L}}
$$

In shoot-through state, the DC link voltage $\left(\mathrm{V}_{\mathrm{i}}\right)$ across the inverter bridge is zero.

$$
\mathrm{V}_{\mathrm{i}}=0
$$

Inductor voltage $\mathrm{V}_{\mathrm{L}}$ in shoot-through state is $\mathrm{V}_{\mathrm{C}}$

$$
\mathrm{V}_{\mathrm{L}}=\mathrm{V}_{\mathrm{C}}
$$

Inductor voltage $\mathrm{V}_{\mathrm{L}}$ in non-shoot through state is $\mathrm{V}_{0}-\mathrm{V}_{\mathrm{C}}$

$$
\mathrm{V}_{\mathrm{L}}=\mathrm{V}_{0}-\mathrm{V}_{\mathrm{C}}
$$

where $\mathrm{V}_{\mathrm{O}}$ is $\mathrm{DC}$ input voltage.

In steady state, average voltage of inductors over one switching period (T) is zero.

$$
\mathrm{V}_{\mathrm{L}}=\frac{\mathrm{T}_{0}\left(\mathrm{~V}_{\mathrm{C}}\right)+\mathrm{T}_{1}\left(\mathrm{~V}_{0}-\mathrm{V}_{\mathrm{C}}\right)}{\mathrm{T}}
$$

where T- Total Switching Period

$\mathrm{T}_{\mathrm{O}^{-}}$Shoot through Period

$\mathrm{T}_{1}$ - Non-Shoot through Period

Simplifying the (5), we get

$$
\frac{\mathrm{V}_{\mathrm{C}}}{\mathrm{V}_{0}}=\frac{\mathrm{T}_{1}}{\mathrm{~T}_{1}-\mathrm{T}_{0}}
$$

Equation (6a) can be rewritten as

$$
V_{C}=\frac{T_{1} V_{0}}{\left(T_{1}-T_{0}\right)}
$$

Likewise, average DC link voltage across inverter bridge can be acquired as below:

$$
\mathrm{V}_{\mathrm{i}}=\frac{\left[\mathrm{T}_{0}(0)+\mathrm{T}_{1}\left(2 \mathrm{~V}_{\mathrm{C}}-\mathrm{V}_{0}\right)\right]}{\mathrm{T}}
$$


Substituting (2) in (7) and simplifying (7), we get

$$
\mathrm{V}_{0}=2 \mathrm{~V}_{\mathrm{C}}
$$

Peak DC-link voltage across inverter bridge can be established as under:

$$
V_{i}=V_{C}-V_{L}=V_{C}-\left(V_{0}-V_{C}\right)=2 V_{C}-V_{0}
$$

Substituting (6b) in (9) and simplifying the (9), we get

$$
\begin{aligned}
& \mathrm{V}_{\mathrm{i}}=\mathrm{V}_{0}\left[\frac{\mathrm{T}_{1}+\mathrm{T}_{0}}{\mathrm{~T}_{1}-\mathrm{T}_{0}}\right]=\mathrm{V}_{0}\left[\frac{\mathrm{T}}{\mathrm{T}_{1}-\mathrm{T}_{0}}\right] \\
& \text { as } \mathrm{T}=\mathrm{T}_{1}+\mathrm{T}_{0}
\end{aligned}
$$

Defining $B=\frac{T}{\left(T_{1}-T_{0}\right)} \geq 1$ as boost factor of inverter, we get

$$
\mathrm{V}_{\mathrm{i}}=\mathrm{B} \cdot \mathrm{V}_{0}
$$

If $\mathrm{M}$ is the modulation index, then output peak phase voltage of the inverter is

$$
\mathrm{V}_{\mathrm{ac}}=\frac{\mathrm{M} \cdot \mathrm{V}_{\mathrm{i}}}{2}
$$

Substituting (11) in E (12), we get

$$
\mathrm{V}_{\mathrm{ac}}=\frac{\mathrm{M} \cdot \mathrm{B} \cdot \mathrm{V}_{0}}{2}
$$

Thus it is obvious from (13) that, output voltage can be varied by varying $M . B=B_{B}=B u c k-B o o s t$ factor that varies from 0 to $\infty$.

Capacitor voltage of impedance network can be derived by substituting $\mathrm{T}_{1}=T-\mathrm{T}_{0}$ in (6b)

$$
V_{C}=\left[\frac{\left(T-T_{0}\right)}{\left(T-T_{0}\right)-T_{0}}\right] V_{0}=\left[\frac{1-\left(\frac{T_{0}}{T}\right)}{1-2\left(\frac{T_{0}}{T}\right)}\right] V_{0}
$$

If duty cycle $D=\frac{T_{0}}{T}$, then Eq. (15) becomes

$$
\mathrm{V}_{\mathrm{C}}=\left[\frac{1-D}{1-2 D}\right] \mathrm{V}_{0}
$$

Boost factor $\mathrm{B}_{\mathrm{B}}$, which is controlled by duty cycle of shoot through zero state is identified by the modulation index ' $\mathrm{m}$ ' as well as the boost factor ' $\mathrm{B}$ '.

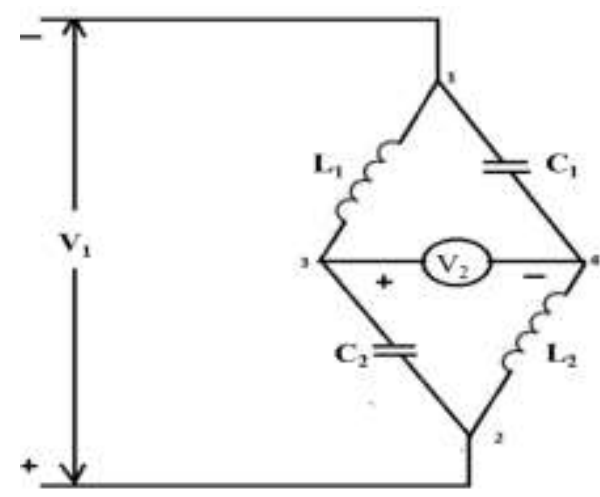

Figure 3. Modified impedance network 
The impedance network is modified in the form of bridge network consisting of four points say 1 to 4 as shown in Figure 3. Assuming current $I_{1}$ entering the network at point 1 , current $I_{2}$ at point 2 as 0 and using Kirchoff's voltage law, the values of series arm inductors $\left(\mathrm{L}_{1}\right.$ and $\left.\mathrm{L}_{2}\right)$ and values of parallel arm capacitors $\left(\mathrm{C}_{1}\right.$ and $\left.\mathrm{C}_{2}\right)$ can be designed as below.

Using Kirchoff's voltage law

$$
\begin{aligned}
& \mathrm{I}_{1} \frac{L}{2}+\mathrm{V}_{2}=\frac{\mathrm{I}_{1}}{2 \mathrm{C}} \\
& \mathrm{V}_{2}=\frac{\mathrm{I}_{1}}{2 \mathrm{C}}-\frac{\mathrm{I}_{1} \mathrm{~L}}{2}
\end{aligned}
$$

Knowing the values of $\mathrm{V}_{2}$ and $\mathrm{I}_{1}$ and assuming suitable value of $\mathrm{C}$, value of $\mathrm{L}$ can be obtained. Simulation has been carried out and a prototype hardware model has been built.

\section{SIMULATION RESULTS}

The Simulink models ${ }^{18}$ of the following cases are carried out by means of MATLAB software.

1. Solar system with closed loop PID controller for RL load

2. Solar system with closed loop PID controller for grid system.

The simulation parameters of constructing boost converter, Impedance-source inverter and controllers are tabulated below in Table 1 and 2. Also the transient and steady state response parameter for PID controller is tabulated in 3 and simulink model consists of the following blocks:

1. MPPT controller based solar panel

2. Boost converter

3. Impedance-Source Inverter

4. RL Load and grid

Table1. Simulation Parameters of Converter and Inverter

\begin{tabular}{ccc}
\hline Boost converter & Impedance-filter & Impedance-source inverter \\
\hline $\mathrm{V}_{\mathrm{in}=40 \mathrm{~V}}$ & $\mathrm{C}_{1}, \mathrm{C}_{2=}$ & $\mathrm{L}_{1}, \mathrm{~L}_{2}, \mathrm{~L}_{3=}$ \\
$\mathrm{C}_{1=} 1000 \mu \mathrm{F}$ & $3000 \mu \mathrm{F}$ & $800 \mathrm{mH}$ \\
$\mathrm{L}_{1=} 15 \mu \mathrm{H}$ & & $\mathrm{C}_{1}, \mathrm{C}_{2}, \mathrm{C}_{3=}$ \\
$\mathrm{C}_{\mathrm{s}=0.6 \mathrm{mf}}$ & $\mathrm{L}_{1}, \mathrm{~L}_{2}=$ & $10 \mu \mathrm{F}$ \\
$\mathrm{C}_{\mathrm{out}}=3000 \mu \mathrm{F}$ & $100 \mathrm{mH}$ & $\mathrm{R}=10 \Omega$ \\
$\mathrm{V}_{\mathrm{o}=} 80 \mathrm{~V}$ & & $\mathrm{~L}=800 \mathrm{mH}$ \\
\hline
\end{tabular}

Table 2. Simulation Parameters of Controller

\begin{tabular}{ccccc}
\hline Type of Controller & $\mathrm{K}_{\mathrm{p}}$ & $\mathrm{K}_{\mathrm{i}}$ & $\mathrm{K}_{\mathrm{d}}$ & $\mathrm{T}_{\mathrm{s}}$ \\
\hline PID & 0.009 & 0.8 & 0.007 & $50 \mu \mathrm{s}$ \\
\hline
\end{tabular}

Table 3. Specifications of Controllers

\begin{tabular}{ccccc}
\hline $\begin{array}{c}\text { Type } \\
\text { of Controller }\end{array}$ & Rise time $(\mathrm{Sec})$ & $\begin{array}{c}\text { Transient Specifications } \\
\text { Peak time }(\mathrm{Sec})\end{array}$ & Settling time $(\mathrm{Sec})$ & Steady state error \\
\hline PID & 1.2 & 2.8 & 2.2 & 5 \\
\hline
\end{tabular}

\subsection{Solar system with closed loop PID controller for RL load without grid system}

The closed loop simulink model shown in Figure 4 comprises of solar model, boost converter, impedance-source inverter (impedance-filter and three-phase inverter), PID controller, RL load etc. is aimed for a switching frequency of $5 \mathrm{kHz}$ and the outcomes of the same are presented below.

The output voltage of $40 \mathrm{~V}$ from solar panel is given to boost converter where it is boosted to nearly $80 \mathrm{~V}$ as shown in Figures 5 and 6.

The firing pulses for three MOSFET switches viz. $\mathrm{M}_{1}, \mathrm{M}_{3}$ and $\mathrm{M}_{5}$ of three-phase inverter, a part of impedance-source inverter is shown in Figure 7. The three output voltages displaced by certain degree of three-phase inverter is shown in Figure 8. The output voltage across connected RL load and output current through connected RL load without grid system are shown in Figures 9 and 10. 
The FFT analysis is obtained as in Figure 11 for solar system with closed loop PID controller for RL Load without grid system. The current total harmonic distortion for PID controller is $4.6 \%$ which is well below the standard.

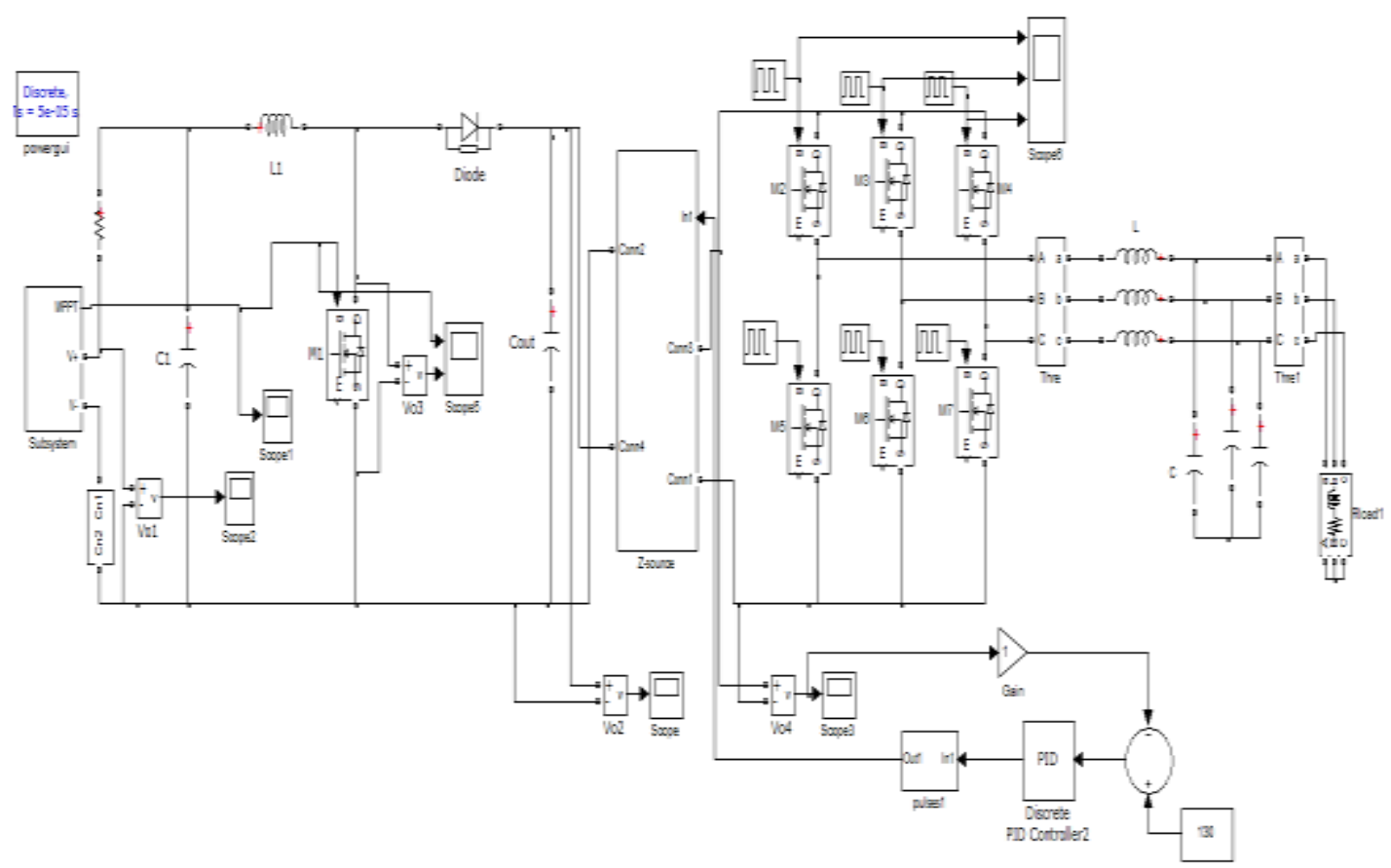

Figure 4. Simulink model-solar system with closed loop PID controller for RL load without grid system

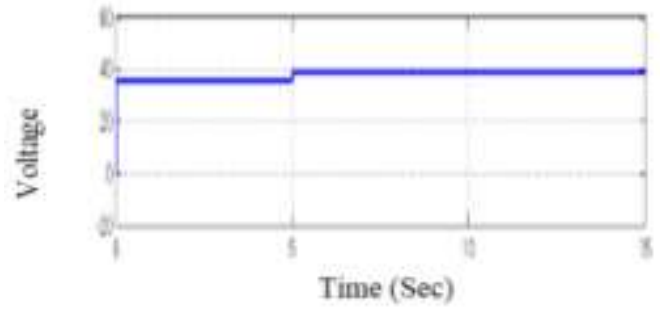

Figure 5. Input voltage of boost converter

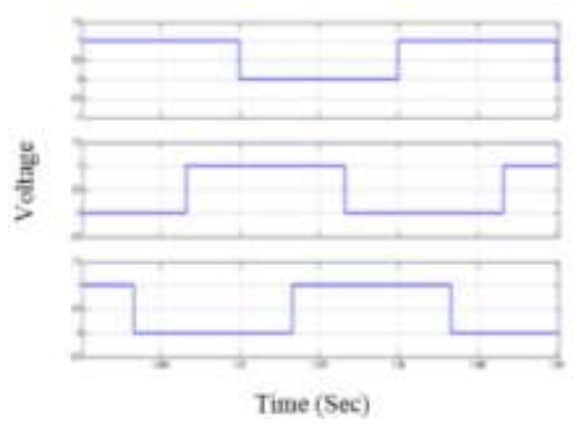

Figure 7. Firing pulses for three phase inverter $\left(\mathrm{M}_{1}, \mathrm{M}_{3}\right.$ and $\left.\mathrm{M}_{5}\right)$

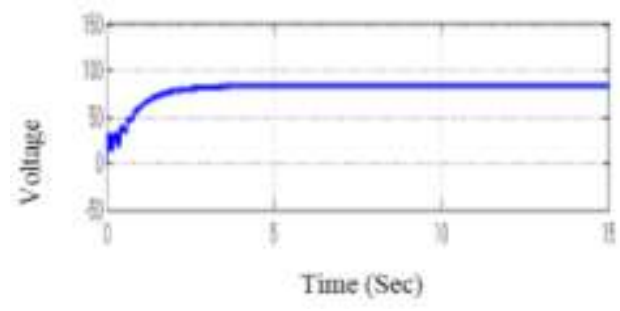

Figure 6. Output voltage of boost converter

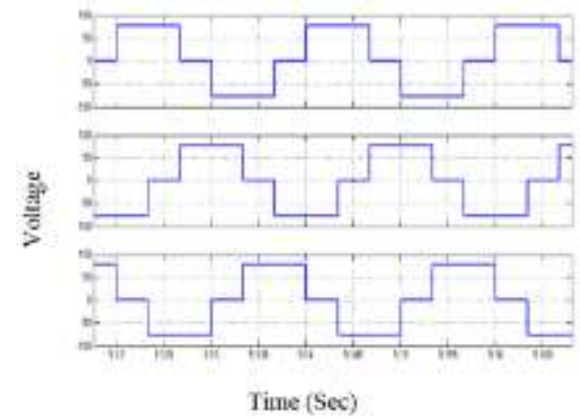

Figure 8. Output voltage of three phase inverter 


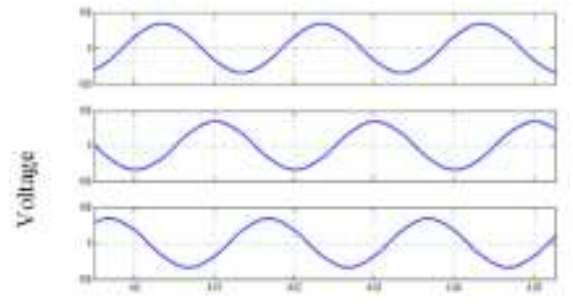

Time (Sec)

Figure 9. Output voltage across RL load without grid system

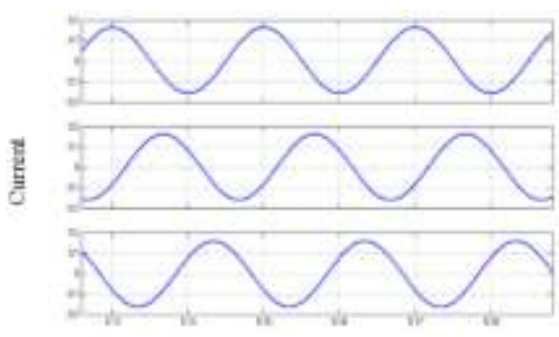

Time (Sec)

Figure 10. Output current through RL load without grid system

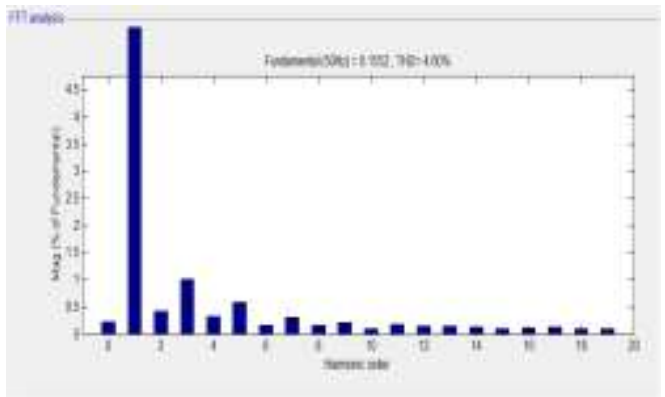

Figure 11. Analysis of current THD

\subsection{Solar system with closed loop PID controller for grid system}

The closed loop simulink model shown in Figure 12 comprises of solar model, boost converter, impedance-source inverter (impedance-filter and three-phase inverter), PID controller, RL Load, grid system etc. is aimed for a switching frequency of $5 \mathrm{kHz}$ and the outcomes of the same are presented below.

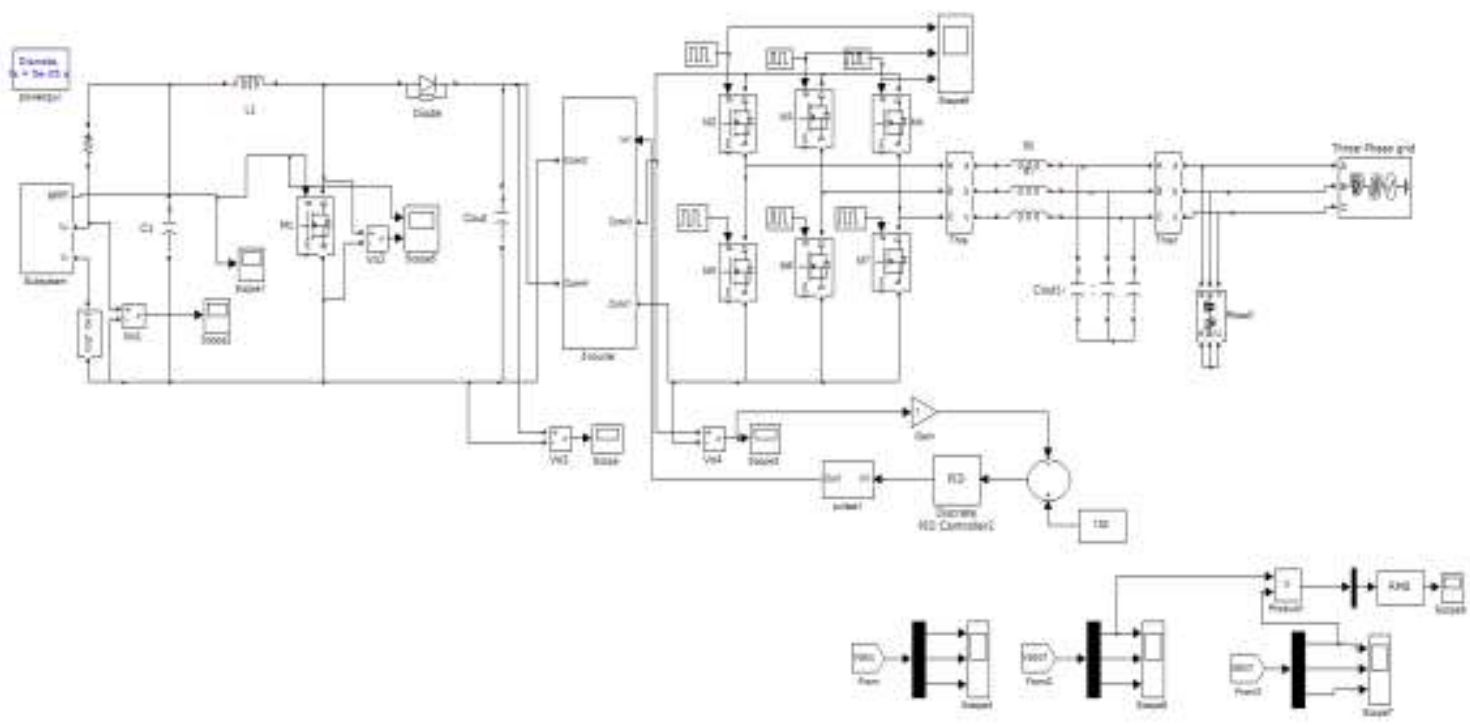

Figure 12. Simulink model -solar system with closed loop PID controller for grid system

The output voltage of $40 \mathrm{~V}$ from solar panel is given to boost converter where it is boosted to nearly $80 \mathrm{~V}$ as shown in Figures 13 and 14. 
The firing pulses for three MOSFET switches viz. $\mathrm{M}_{1}, \mathrm{M}_{3}$ and $\mathrm{M}_{5}$ of three-phase inverter, a part of impedance-source inverter is shown in Figure 15. The three output voltages displaced by certain degree of three-phase inverter is shown in Figure 16. The output voltage across connected grid and output current through connected grid are shown in Figures 17 and 18.

The FFT analysis is obtained as in Figure 19 for solar system with closed loop PID controller for grid system. The current total harmonic distortion with PID controller is $3.05 \%$ which is comparatively less. Different THD levels with RL Load and grid system of solar system are tabulated in Table 4.

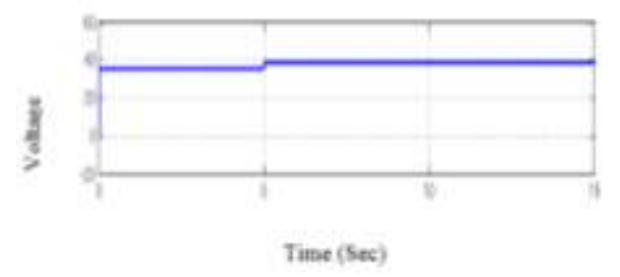

Figure 13. Input voltage of boost converter

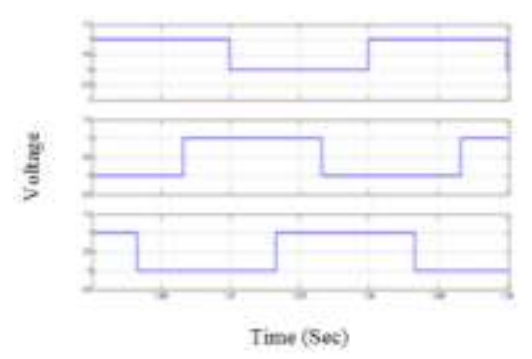

Figure 15. Firing pulses for three phase inverter $\left(\mathrm{M}_{1}, \mathrm{M}_{3}\right.$ and $\left.\mathrm{M}_{5}\right)$

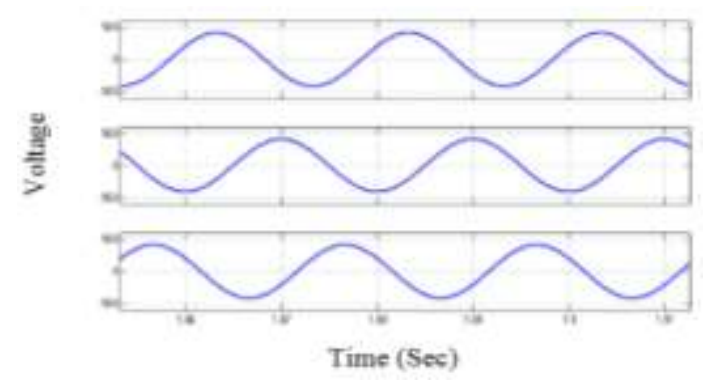

Figure 17. Output voltage across grid system

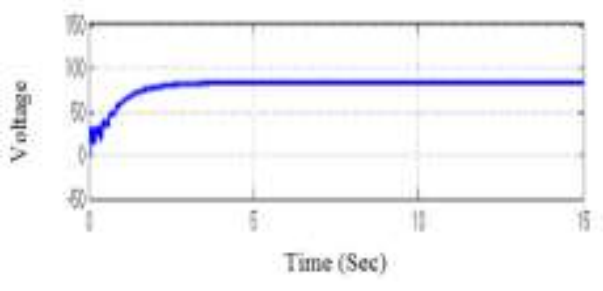

Figure 14. Output voltage of boost converter

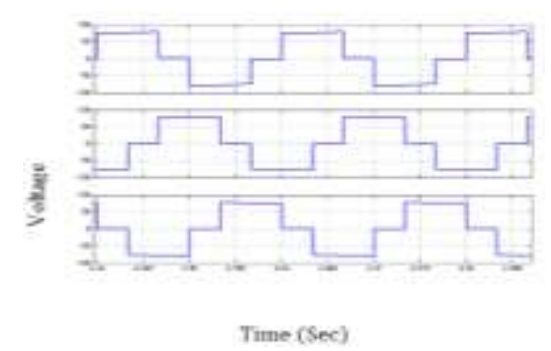

Figure 16. Output voltage of three phase inverter

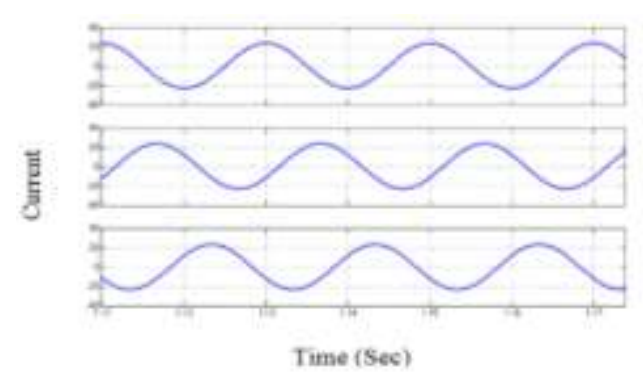

Figure 18. Output current through grid system

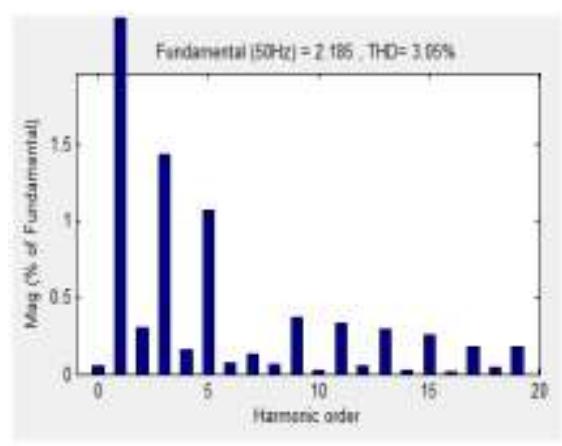

Figure 19. Analysis of current THD 
Table 4. THD with RL Load and Grid

\begin{tabular}{ccc} 
Type of Controller & THD for RL-Load without Grid System & THD with Grid System \\
\hline PID & $4.60 \%$ & $3.05 \%$ \\
\hline
\end{tabular}

\section{EXPERIMENT RESULTS:}

The PIC controller PIC16F84A is preferred for this solar energy system for the creation of all control signals to the boost converter and impedance-source inverter. These signals are amplified by driver ICs IR 2110 and IRF 840. The input voltage required both by driver and microcontroller circuits are provided by LM 7812 voltage regulator.

The Figure 20 is prototype hardware model of impedance-source inverter for solar energy system. Figure 21 shows the output voltage of solar panel. Switching pulses and output voltage of boost converter are in Figures 22. The output voltage across RL load is shown in Figure 23.

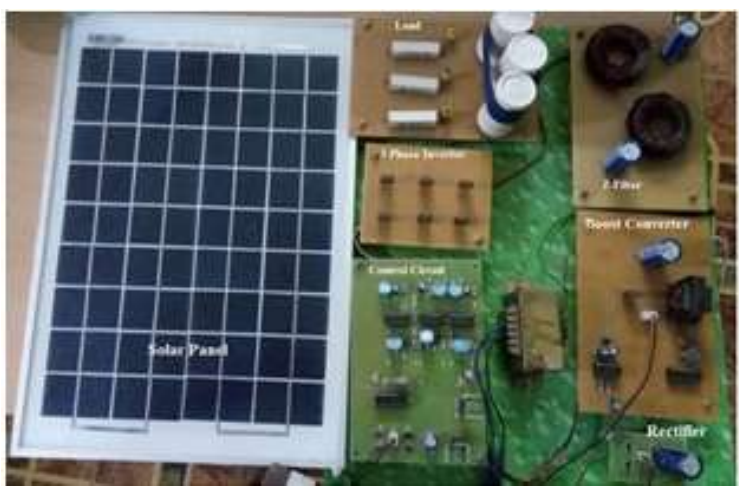

Figure 20. Prototype hardware model-impedancesource inverter for solar energy system

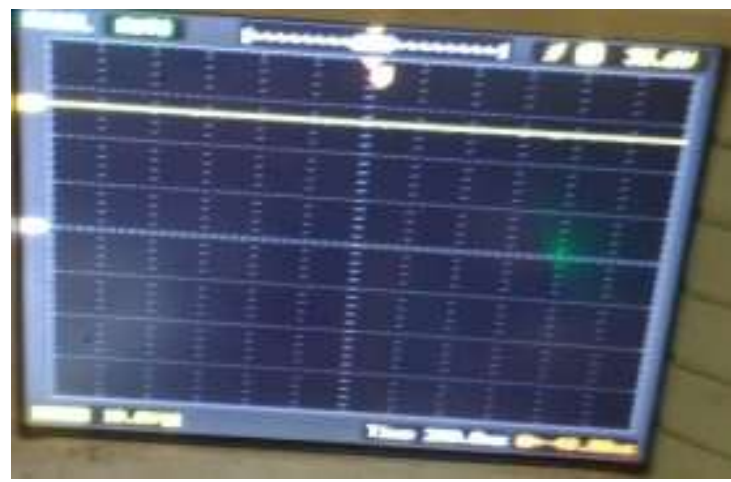

Figure 22. Output voltage of boost converter

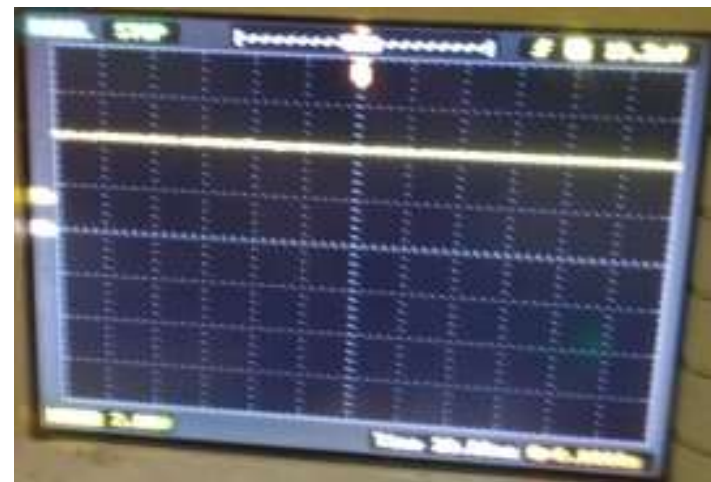

Figure 21. Output voltage of solar panel

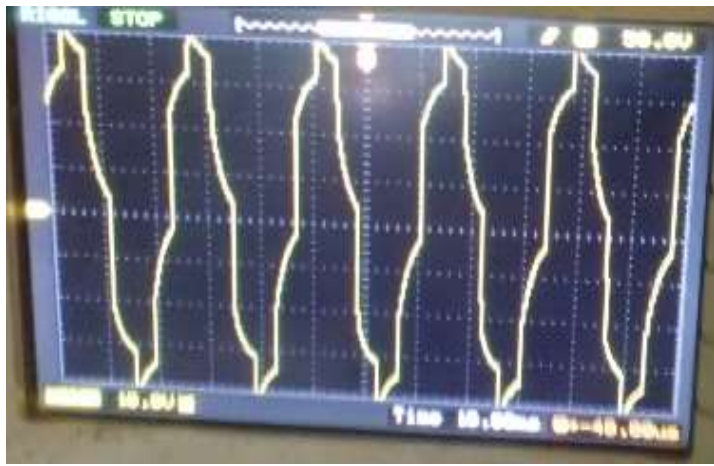

Figure 23. Output voltage across RL load

\section{CONCLUSION}

A solar based impedance-source inverter with PID controllers for both RL load without grid and with grid system are analysed and compared. The accomplishment demonstrates that the performance of the system with grid was better with regard to that of RL load without grid system. Digital simulation and prototype hardware modelling of solar based impedance-source inverter with PID controllers is established and the output obtained under transient and steady state conditions. The future enhancement of this work is to simulate for wind energy system and to realize a hardware model of the system proposed. 


\section{REFERENCES}

[1] Mukund R. Patel: "Wind and solar power systems design, analysis and operation." Second edn., CRC Taylor and Francis Group, pp.163-168.

[2] R.Gules, J.De Pellegrin Pacheco, H. Leaes Hey, J. Imhoff: “A maximum power point tracking system with parallel connection for PV stand-alone applications”, IEEE Trans. (2008), 55, (7), pp. 2674-2683.

[3] Aashoor, F.A.O.; Robinson, F.V.P: "A variable step size perturb and observe algorithm for photovoltaic maximum power point tracking," IEEE (2012)

[4] Al-Diab, A.; Sourkounis, C: "Variable step size P\&O MPPT algorithm for PV systems," IEEE (2010)

[5] H. Bounechba, A. Bouzid,K.Nabti, H. Benalla: "Comparison of P\&O and fuzzy logic in Maximum power Point Tracker for PV system" Technologies and Materials for Renewable Energy, Environment and Sustainability (2014) pp.677-684 .

[6] www.greenrhinoenergy.com

[7] www.bryan.buckley.com

[8] John Marshal: "Single input DC-DC converter for hybrid distributed energy generators with maximum utilization using DSP controller", IJERA, 2012, pp. 989-993.

[9] Shuouitao Yang, F Z Feng, Qin Lei, Ryosuke Inoshita, Zhaoming Qian: "Current-fed quasi-Z-source inverter with voltage buck-boost and regeneration capability” IEEE, 2010, pp. 882-892.

[10] F Z Peng, Yi Huang: "Z-source inverter for power conditioning and utility interface of renewable energy sources"

[11] Y M Chen and S C Hung:"Multi-input inverter for grid connected hybrid PV/wind power system", IEEE Trans. 2007, pp. 850-856.

[12] Yi Huang, Miaosen Shen and F Z Peng:

[13] “Z-source inverter for residential PV systems” IEEE, 2006, pp. 1776-1782.

[14] ZhiqiangGao, KeShen, Jianze Wang and Qichao Chen:“An improved control method for inductive load of Z-source inverter" IEEE, 2010.

[15] Farzad Sedaghati, Ebrahim Babaei: “Double input Z-source DC-DC converter” IEEE, 2011.

[16] Reza Gharakhany, Mustafa Mohamadian and Ali YazdianVarjani: "Reactive power compensation using Z-source based PV system" IEEE, 2009.

[17] Fang Zheng Peng: 'Z-Source Inverter', IEEE Transactions on Industry Applications, 2003, 39, (2), pp. 504-510

[18] B. Justus Rabi, R. Arumugam: 'Harmonics Study and Comparison of Z-Source Inverter with Traditional Inverters', American Journal of Applied Sciences', 2005, 2, (10), pp. 1418-1426

[19] S. Kamalakkannan, D.Kirubakaran: 'Comparative Analysis of Grid Connected Photovoltaic based Z-Source Inverter with PI and PID Controllers', Journal of Computational and Theoretical Nano science, 1, (14), pp. 577-584.

\section{BIOGRAPHIES OF AUTHORS}
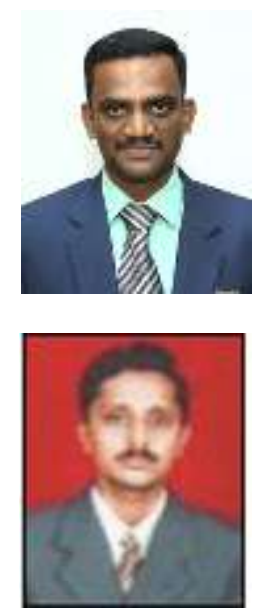

S. Kamalakkannan obtained his M.E degree from Bharathidasan University, Trichy in the year 2001. He is a research scholar at Sathyabama University, Chennai. He has more than 15 years of teaching experience in Engineering College and a life member in ISTE. He has published several research papers in the area of Power Electronics. He is currently working as Assistant Professor in St. Joseph's Institute of Technology, Chennai, India
Dr. D. Kirubakaran has obtained M.E. degree from Bharathidasan University, Trichy in the year 2000 and Ph.D. degree from Anna University, Chennai in the year 2010. His area of interest is Induction Heating and Renewable Energy Systems. He has published several research papers in the area of Induction Heating. He has more than 15 years of teaching experience. He is a life member of ISTE. He is currently working as a Professor and Head in the Department of Electrical and Electronics Engineering, St. Joseph's Institute of Technology, Chennai, India. 